\title{
ZARZĄDZANIE GMINA W ASPEKCIE WSPIERANIA ROZWOJU PRZEDSIĘBIORCZOŚCI
}

\author{
Milena Ociesa \\ Politechnika Częstochowska \\ Wydział Zarządzania
}

\begin{abstract}
Streszczenie: W artykule przedstawiono zadania gminy oraz zaprezentowano jej rolę w zakresie rozwoju przedsiębiorczości. Ukazano dochodowe i wydatkowe instrumenty gminy służące wspieraniu przedsiębiorczości. Celem artykułu jest analiza przedsiębiorczości rozpatrywanej w kategorii prowadzonej działalności gospodarczej na terenie miast na prawach powiatu należących do województwa śląskiego oraz identyfikacja działań wspierania przedsiębiorczości w badanej gminie o najkorzystniejszych wskaźnikach.
\end{abstract}

Słowa kluczowe: instrumenty wspierania przedsiębiorczości, gmina, miasto na prawach powiatu, przedsiębiorczość, samorząd terytorialny

DOI: 10.17512/znpcz.2016.2.20

\section{Wprowadzenie}

Przedsiębiorstwa, prowadząc działalność gospodarczą, podejmują decyzje o umiejscowieniu tej działalności. Wśród wielu czynników decydujących o wyborze lokalizacji ważne znaczenie posiadają działania władz gminy.

Gmina wpływa na kształtowanie rozwoju przedsiębiorstw zlokalizowanych na jej terenie, tworząc zachęty dla obecnych i potencjalnych przedsiębiorstw. W gospodarce rynkowej coraz większego znaczenia nabiera oddziaływanie władz lokalnych zmierzające do wykreowania najbardziej korzystnych warunków funkcjonowania przedsiębiorstw, a w konsekwencji pobudzania gospodarki lokalnej jako całości (Leśniewski 2013, s. 30).

\section{Zadania gminy oraz jej rola w zakresie rozwoju przedsiębiorczości}

Wspólnotę samorządową stanowi z mocy prawa ogół mieszkańców jednostek zasadniczego podziału terytorialnego (Konstytucja..., art. 16). Samorząd to przestrzeń i ludzie, którzy z założenia mają sami sobą rządzić poprzez wybór władzy. Składa się na nią ponadto różnorodność form organizacyjnych aktywności ludzi powiązanych ze sobą kombinacją sieci o rynkowym i społecznym, ale także mentalnym charakterze. Ludzie ci, i ich organizacje, funkcjonują ponadto w turbulentnym otoczeniu, dążąc jednocześnie do względnej stabilizacji (Gawroński 2010, s. 32).

Zadaniami publicznymi wykonywanymi przez jednostkę samorządu terytorialnego są zadania własne i zlecone. Zadania własne to zadania publiczne służące zaspokajaniu potrzeb wspólnoty samorządowej. Natomiast zadania zlecone są wy- 
konywane z uzasadnionych potrzeb państwa (Konstytucja..., art. 166). Do zakresu działania gminy należą wszystkie sprawy publiczne o znaczeniu lokalnym. Zadania własne gminy obejmują w szczególności sprawy (Ustawa o samorządzie gminnym, art. 6-7):

- ładu przestrzennego, gospodarki nieruchomościami, ochrony środowiska i przyrody oraz gospodarki wodnej;

- gminnych dróg, ulic, mostów, placów oraz organizacji ruchu drogowego;

- wodociągów i zaopatrzenia w wodę, kanalizacji, usuwania i oczyszczania ścieków komunalnych, utrzymania czystości i porządku oraz urządzeń sanitarnych, wysypisk i unieszkodliwiania odpadów komunalnych, zaopatrzenia w energię elektryczną i cieplną oraz gaz;

- działalności w zakresie telekomunikacji;

- lokalnego transportu zbiorowego;

- ochrony zdrowia;

- pomocy społecznej, w tym ośrodków i zakładów opiekuńczych;

- wspierania rodziny i systemu pieczy zastępczej;

- gminnego budownictwa mieszkaniowego;

- edukacji publicznej;

- kultury, w tym bibliotek gminnych i innych instytucji kultury oraz ochrony zabytków i opieki nad zabytkami;

- kultury fizycznej i turystyki, w tym terenów rekreacyjnych i urządzeń sportowych;

- targowisk i hal targowych;

- zieleni gminnej i zadrzewień;

- cmentarzy gminnych;

- porządku publicznego i bezpieczeństwa obywateli oraz ochrony przeciwpożarowej i przeciwpowodziowej, w tym wyposażenia i utrzymania gminnego magazynu przeciwpowodziowego;

- utrzymania gminnych obiektów i urządzeń użyteczności publicznej oraz obiektów administracyjnych;

- polityki prorodzinnej, w tym zapewnienia kobietom w ciąży opieki socjalnej, medycznej i prawnej;

- wspierania i upowszechniania idei samorządowej, w tym tworzenia warunków do działania i rozwoju jednostek pomocniczych i wdrażania programów pobudzania aktywności obywatelskiej;

- promocji gminy;

- współpracy i działalności na rzecz organizacji pozarządowych oraz określonych podmiotów prowadzących działalność pożytku publicznego;

- współpracy ze społecznościami lokalnymi i regionalnymi innych państw.

Funkcjonowanie gmin w gospodarce rynkowej należy rozpatrywać nie tylko w wąskim ujęciu jako dostarczyciela usług publicznych, ale znacznie szerzej. Gminę należy potraktować jako jednostkę realizującą funkcje: zarządzania, działania marketingowe, prawne oraz polityczne, których stan ogranicza bądź stymuluje efektywność funkcjonowania innych podmiotów gospodarki rynkowej. Gospodarka samorządu jest czynnikiem wpływającym na dynamikę przedsiębiorczości lo- 
kalnej, ponieważ w pierwszym rzędzie to samorząd terytorialny stanowi otoczenie dla przedsiębiorstw. Gmina winna tworzyć tak zwany klimat przedsiębiorczości, kulturę przedsiębiorczości (Leśniewski 2013, s. 30).

Przedsiębiorczość - mimo że jest pojęciem często używanym - nie doczekała się jednoznacznej definicji. Wynika to przede wszystkim z tego, że koncepcja przedsiębiorczości obejmuje równocześnie fakt bycia przedsiębiorcą i menedżerem, ponoszenia ryzyka, generowania innowacji i poszukiwania okazji rynkowych (Piotrowski 2012, s. 135). Przedsiębiorczość może być rozumiana w ujęciu czynnościowym (działania podejmowane w związku z ,załatwieniem spraw”) i atrybutowym (zespół ludzkich cech związanych z aktywnością, skłonnością do ryzyka, innowacyjnością) (Kola-Bezka 2013, s. 28).

Przedsiębiorcą w rozumieniu ustawy o swobodzie działalności gospodarczej jest osoba fizyczna, osoba prawna i jednostka organizacyjna niebędąca osobą prawną, której odrębna ustawa przyznaje zdolność prawną - wykonująca we własnym imieniu działalność gospodarczą (Ustawa o swobodzie działalności gospodarczej, art. 4). Przedsiębiorca jest często definiowany jako osoba zaczynająca własny, nowy i mały biznes (Drucker 2015, s. 25).

Gmina pełni ważną rolę w kształtowaniu warunków działania podmiotów gospodarczych w ramach danego układu lokalnego. Wpływ gminy na rozwój przedsiębiorstw może mieć charakter pozytywny i/lub negatywny (Leśniewski 2013, s. 30).

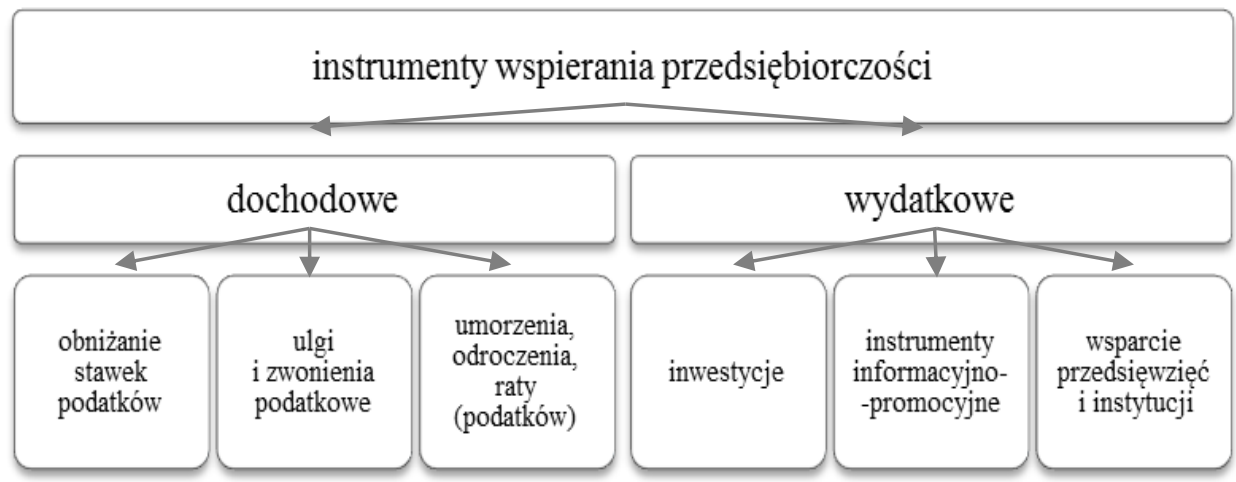

Rysunek 1. Podział instrumentów wpierania przedsiębiorczości w samorządzie terytorialnym

Źródło: Opracowanie własne na podstawie (Dziemianowicz i in. 2000, s. 8-12)

Praktycznie każde działanie gminy ma bezpośredni lub pośredni wpływ na lokalne firmy. Przyjęto, że instrumenty wspierania przedsiębiorczości można podzielić najogólniej na dochodowe i wydatkowe (Dziemianowicz i in. 2000, s. 8). Zostały one wyszczególnione na Rysunku 1.

$\mathrm{W}$ grupie instrumentów dochodowych znajdują się wszelkiego rodzaju zwolnienia i ulgi podatkowe, a także obniżenia stawek lokalnych. Gminy mogą również odraczać, umarzać, rozkładać na raty oraz zaniechać poboru w zakresie podatków i opłat stanowiących ich dochody (Dziemianowicz i in. 2000, s. 8-9). Oczekiwania 
inwestorów, dotyczące ulg w podatkach lokalnych, są przejawem chęci obniżenia kosztów działalności, choć wysokość zwolnień udzielanych przez władze lokalne jest zwykle niewielka, szczególnie z punktu widzenia dużych firm i międzynarodowych korporacji. Uwzględnienie tego elementu w strategii inwestycyjnej jest jednak często traktowane jako wyznacznik stosunku władz do potencjalnych inwestorów (Jerschinia i in. 2010, s. 19). Polityka podatkowa lub zachęty finansowe stosowane przez władze lokalne są jednym z czynników determinujących napływ inwestorów (por. European Cities Monitor, 2011).

Natomiast najważniejszymi instrumentami wydatkowymi wydają się być inwestycje dokonywane w gminie (Dziemianowicz i in. 2000, s. 9). Inwestycje realizowane przez samorządy lokalne wpływają na poziom życia mieszkańców, a poprzez rozwój infrastruktury komunalnej mogą zachęcić inwestorów prywatnych do podejmowania na ich terenie działalności gospodarczej (Łukomska-Szarek 2007, s. 150). Inwestycje władz gminnych w sferze infrastruktury technicznej stwarzają warunki do tego, aby zarówno potencjalne, jak i już istniejące podmioty gospodarcze mogły na ich terenie prowadzić swoją działalność (Zimny 2008, s. 19). Obok nakładów czysto inwestycyjnych gminy mogą przeznaczać część swoich budżetów na wsparcie różnego rodzaju przedsięwzięć i instytucji służących rozwojowi gospodarczemu. W grupie instrumentów wydatkowych znajdują się również instrumenty informacyjno-promocyjne (Dziemianowicz i in. 2000, s. 10-12).

U podstaw przesłanek strategii promocji jednostek terytorialnych leżą następujące korzyści, które mogą wyniknąć z podejmowanych działań oraz wpływać na konkurencyjność regionalną (Raszkowski 2012, s. 158):

- pozyskanie inwestorów zewnętrznych,

- ożywienie rodzimego inwestora,

- pozyskanie turystów,

- infrastruktura dla rozwoju przedsiębiorstw,

- otoczenie dla biznesu,

- lokalizacja ważnych instytucji,

- organizacja imprez o wysokiej randze,

- realizacja dużych projektów infrastrukturalnych.

Samorządowe starania, których celem jest pozyskanie nowych inwestorów, cieszą się coraz większym zainteresowaniem społeczności lokalnych (Jarczewski 2012, s. 11).

\section{Przedsiębiorczość w miastach na prawach powiatu województwa śląskiego - wyniki badań}

Podmiotem badań było 19 miast na prawach powiatu należących do województwa śląskiego. Są to wszystkie miasta o tym statusie w województwie śląskim. Najważniejsze charakterystyki badanych gmin zostały przedstawione w Tabeli 1 . 
Tabela 1. Charakterystyka miast na prawach powiatu województwa śląskiego w 2014 roku (w porządku alfabetycznym)

\begin{tabular}{|c|c|c|c|c|}
\hline Lp. & Miasto & Powierzchnia $\left[\mathrm{km}^{2}\right]$ & Liczba ludności & $\begin{array}{c}\text { Dochody ogółem } \\
\text { budżetu miasta } \\
\text { na jednego } \\
\text { mieszkańca }\end{array}$ \\
\hline 1. & Bielsko-Biała & 125 & 173013 & 4633 \\
\hline 2. & Bytom & 69 & 172306 & 4032 \\
\hline 3. & Chorzów & 33 & 110337 & 4384 \\
\hline 4. & Częstochowa & 160 & 230123 & 4555 \\
\hline 5. & Dąbrowa Górnicza & 189 & 123376 & 6731 \\
\hline 6. & Gliwice & 134 & 184415 & 7098 \\
\hline 7. & Jastrzębie-Zdrój & 85 & 90794 & 3655 \\
\hline 8. & Jaworzno & 153 & 93331 & 4326 \\
\hline 9. & Katowice & 165 & 301834 & 5326 \\
\hline 10. & Mysłowice & 66 & 75037 & 3793 \\
\hline 11. & Piekary Śląskie & 40 & 56755 & 3512 \\
\hline 12. & Ruda Śląska & 78 & 140669 & 4127 \\
\hline 13. & Rybnik & 148 & 140052 & 4777 \\
\hline 14. & Siemianowice Śląskie & 25 & 68634 & 3743 \\
\hline 15. & Sosnowiec & 91 & 209274 & 3685 \\
\hline 16. & Świętochłowice & 13 & 51494 & 3672 \\
\hline 17. & Tychy & 82 & 128621 & 5109 \\
\hline 18. & Zabrze & 80 & 177188 & 4624 \\
\hline 19. & Żory & 65 & 62051 & 3711 \\
\hline
\end{tabular}

Źródło: Opracowanie własne na podstawie danych Głównego Urzędu Statystycznego (Statystyczne Vademecum Samorządowca)

Powierzchnia i liczba ludności w poddanych badaniu gminach jest dość zróżnicowana. Natomiast wartość dochodów ogółem budżetu miasta na mieszkańca zawiera się w przedziale od około 3,5 tys. zł do około 7 tys. zł.

We wszystkich badanych miastach w latach 2010-2014 dominowały podmioty gospodarcze należące do sektora prywatnego, stanowiąc 90\%-100\% wszystkich działających podmiotów gospodarczych, z czego większość stanowily osoby fizyczne prowadzące działalność gospodarczą. Dominującą sekcją działalności we wszystkich badanych gminach była sekcja G, czyli handel hurtowy i detaliczny oraz naprawa pojazdów samochodowych, włączając motocykle. Podmioty należące do tej sekcji stanowiły około $30 \%$ podmiotów. Znacznymi sekcjami działalności było także budownictwo, przetwórstwo przemysłowe, działalność związana z obsługą rynku nieruchomości oraz działalność profesjonalna, naukowa i techniczna. Natomiast według klas wielkości znacznie dominowały podmioty gospodarcze zatrudniające od zera do dziewięciu pracowników (Tabela 2). 
Tabela 2. Podmioty gospodarcze według sektora własnościowego, sekcji oraz klas wielkości dominujące w latach 2010-2014 w miastach na prawach powiatu województwa śląskiego

\begin{tabular}{|c|c|}
\hline Kryterium & Charakterystyka \\
\hline Sektor własnościowy & $\begin{array}{c}90 \%-100 \% \text { podmiotów gospodarczych w badanych miastach należy do } \\
\text { sektora prywatnego, z czego większość stanowią osoby fizyczne prowadzą- } \\
\text { ce działalność gospodarczą }\end{array}$ \\
\hline Sekcja PKD 2007 & $\begin{array}{c}\text { Około 30\% podmiotów gospodarczych należy do sekcji G (handel hurtowy } \\
\text { i detaliczny; naprawa pojazdów samochodowych, włączając motocykle), } \\
\text { około 10\% podmiotów należy do sekcji F (budownictwo), w niektórych } \\
\text { miastach 10\%-15\% podmiotów należy do sekcji C (przetwórstwo przemy- } \\
\text { słowe), do sekcji L (działalność związana z obsługą rynku nieruchomości) } \\
\text { oraz do sekcji M (działalność profesjonalna, naukowa i techniczna) }\end{array}$ \\
\hline Klasa wielkości & Około 95\% podmiotów gospodarczych zatrudnia 0-9 pracowników \\
\hline
\end{tabular}

Źródło: Opracowanie własne na podstawie danych Głównego Urzędu Statystycznego (Bank

Danych Lokalnych)

Głównym przedmiotem badań była przedsiębiorczość rozpatrywana w kategorii prowadzonej działalności gospodarczej. W celu porównania rozwoju przedsiębiorczości na terenach badanych gmin zastosowany został wskaźnik przedsiębiorczości, liczony jako liczba podmiotów gospodarczych przypadająca na 10 tys. mieszkańców, ze względu na zróżnicowanie wielkości badanych gmin. Wskaźnik ten został przedstawiony na Rysunku 2.

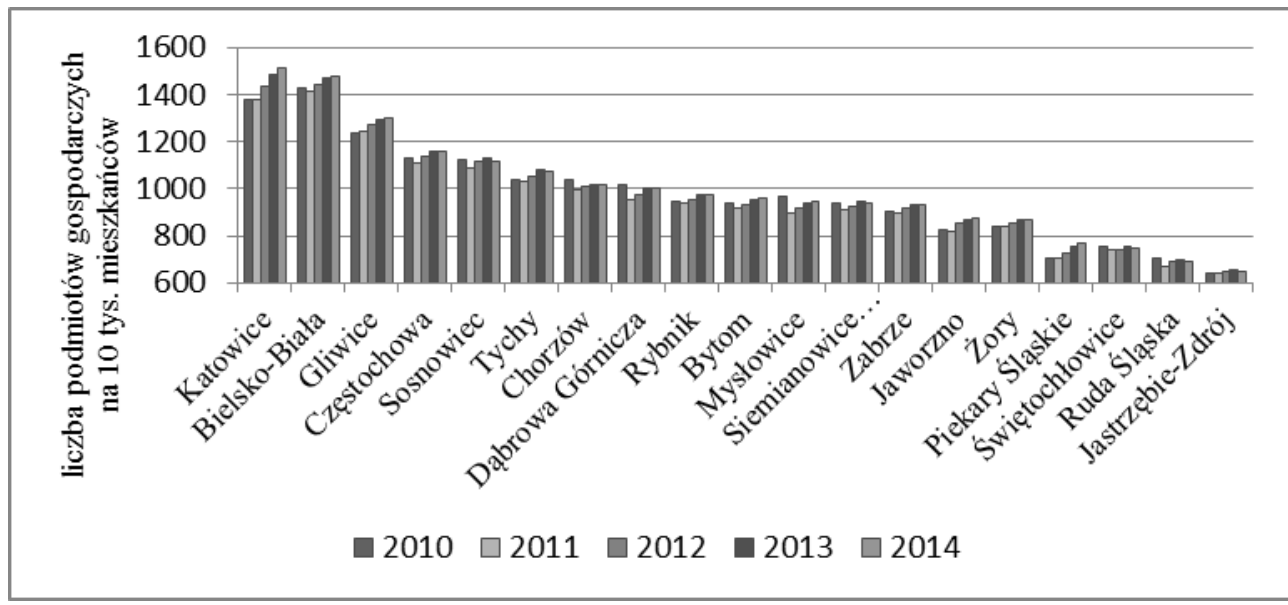

Rysunek 2. Wskaźnik przedsiębiorczości miast na prawach powiatu województwa śląskiego

Wskaźnik liczony jako liczba podmiotów gospodarczych przypadająca na 10 tys. mieszkańców.

Źródło: Opracowanie własne na podstawie danych Głównego Urzędu Statystycznego (Bank Danych Lokalnych) 
Wskaźnik przedsiębiorczości przybierał różne wielkości w poszczególnych gminach. Najwyższą wartość osiągnął w Katowicach i Bielsku-Białej. Natomiast najniższą w Jastrzębiu-Zdroju oraz w Rudzie Śląskiej.

Wskaźnikiem obrazującym rozwój lub spadek przedsiębiorczości jest różnica pomiędzy podmiotami nowo zarejestrowanymi a wyrejestrowanymi na 10 tys. ludności. Wskaźnik ten został obliczony na podstawie danych Głównego Urzędu Statystycznego o podmiotach nowo zarejestrowanych na 10 tys. mieszkańców oraz o podmiotach wyrejestrowanych na 10 tys. mieszkańców. Wskaźnik ten został przedstawiony w Tabeli 3 .

Tabela 3. Różnica pomiędzy podmiotami nowo zarejestrowanymi a wyrejestrowanymi na 10 tys. ludności w latach 2010-2014 w miastach na prawach powiatu województwa śląskiego

\begin{tabular}{|c|c|c|c|c|c|}
\hline \multirow{2}{*}{ Miasto } & \multicolumn{5}{|c|}{ Rok } \\
\cline { 2 - 6 } & 2010 & 2011 & 2012 & 2013 & 2014 \\
\hline Bielsko-Biała & 58 & -14 & 33 & 23 & 8 \\
\hline Bytom & 30 & -18 & 12 & 12 & 4 \\
\hline Chorzów & 38 & -41 & 11 & 3 & 2 \\
\hline Częstochowa & 41 & -19 & 24 & 12 & 1 \\
\hline Dąbrowa Górnicza & 49 & -72 & 20 & 21 & 0 \\
\hline Gliwice & 53 & -2 & 32 & 19 & 2 \\
\hline Jastrzębie-Zdrój & 26 & 1 & 6 & 6 & -6 \\
\hline Jaworzno & 38 & -6 & 28 & 10 & 5 \\
\hline Katowice & 63 & -7 & 49 & 36 & 17 \\
\hline Mysłowice & 50 & -72 & 15 & 18 & 8 \\
\hline Piekary Śląskie & 43 & -4 & 26 & 20 & 9 \\
\hline Ruda Śląska & 34 & -37 & 16 & 8 & -8 \\
\hline Rybnik & 58 & -12 & 16 & 18 & 5 \\
\hline Siemianowice Śląskie & 48 & -30 & 14 & 15 & -7 \\
\hline Sosnowiec & 44 & -39 & 18 & 7 & -18 \\
\hline Świętochłowice & 35 & -18 & 0 & 8 & -8 \\
\hline Tychy & 38 & -7 & 25 & 26 & -4 \\
\hline Zabrze & 34 & -10 & 21 & 9 & -1 \\
\hline Żory & 37 & 1 & 14 & 11 & 7 \\
\hline
\end{tabular}

Źródło: Opracowanie własne na podstawie danych Głównego Urzędu Statystycznego (Bank Danych Lokalnych)

Analiza różnicy pomiędzy podmiotami nowo zarejestrowanymi a wyrejestrowanymi wykazała podobną tendencję we wszystkich badanych gminach. Najwięcej nowych podmiotów gospodarczych powstało w 2010 roku, lecz w kolejnym, 2011 roku, więcej podmiotów zostało wyrejestrowanych niż zarejestrowanych. Prawdopodobnie wiele podmiotów zarejestrowanych w 2010 roku nie przetrwało na ryn$\mathrm{ku}$. W latach 2012-2013 więcej podmiotów gospodarczych powstało niż zostało wyrejestrowanych. Natomiast w roku 2014 wskaźnik ten był niższy (w niektórych gminach nawet ujemny). Liderem wśród badanych miast pod względem większej 
liczby powstawania nowych firm niż ich wyrejestrowywania były Katowice. Może to wynikać z faktu, że Katowice oprócz bycia miastem powiatowym są także stolicą województwa śląskiego.

\section{Identyfikacja dzialań wspierających przedsiębiorczość przez samorząd terytorialny na przykładzie miasta Katowice}

Miasto Katowice wyprzedza pod względem rozwoju przedsiębiorczości pozostałe miasta na prawach powiatu województwa śląskiego. W związku z tym zostaną zidentyfikowane dochodowe i wydatkowe instrumenty wspierania przedsiębiorczości dla tej gminy.

W latach 2010-2014 miasto Katowice osiągnęło następujące dochody podatkowe: udziały we wpływach z podatku dochodowego od osób prawnych, udziały we wpływach z podatku dochodowego od osób fizycznych, podatek dochodowy od osób fizycznych opłacany w formie karty podatkowej, podatek rolny, podatek leśny, podatek od nieruchomości, podatek od środków transportowych, podatek od czynności cywilnoprawnych, wpływy z opłaty skarbowej oraz wpływy z opłaty eksploatacyjnej (por. Sprawozdanie z wykonania budżetu Miasta Katowice...).

Tabela 4. Skutki obniżeń, ulg, zwolnień, umorzeń i odroczeń podatków w Katowicach w latach 2010-2014 [w zl]

\begin{tabular}{|c|c|c|c|c|c|}
\hline Rok & $\begin{array}{c}\text { Dochody } \\
\text { podatkowe }\end{array}$ & $\begin{array}{c}\text { Obniżenie } \\
\text { górnych stawek } \\
\text { podatków }\end{array}$ & $\begin{array}{c}\text { Udzielone ulgi } \\
\text { i zwolnienia }\end{array}$ & $\begin{array}{c}\text { Umorzenie } \\
\text { zaległości } \\
\text { podatkowych }\end{array}$ & $\begin{array}{c}\text { Rozłożenie na raty, } \\
\text { odroczenie terminu } \\
\text { płatności, zwolnienie } \\
\text { z obowiązu } \\
\text { pobrania, } \\
\text { ograniczenie poboru }\end{array}$ \\
\hline $\mathbf{2 0 1 0}$ & 555495973,00 & 9280994,00 & 1163968,46 & 1303,80 & 848684,14 \\
\hline $\mathbf{2 0 1 1}$ & 592116780,15 & 13215196,79 & 441835,27 & 187152,96 & 540707,40 \\
\hline $\mathbf{2 0 1 2}$ & 581321272,82 & 16587686,14 & 407520,42 & 30445,90 & 743438,26 \\
\hline $\mathbf{2 0 1 3}$ & 610427820,74 & 17826082,70 & 817282,23 & 719,00 & 78269,80 \\
\hline $\mathbf{2 0 1 4}$ & 638385076,13 & 19310347,20 & 690519,19 & 3232,00 & 109239,00 \\
\hline
\end{tabular}

Źródło: Opracowanie własne na podstawie danych ze sprawozdań z wykonania budżetu Miasta Katowice

W mieście Katowice zostały zastosowane dochodowe instrumenty wspierania przedsiębiorczości: obniżanie górnych stawek podatków lokalnych, stosowanie ulg i zwolnień podatkowych oraz umarzanie zaległości podatkowych, rozkładanie na raty lub odraczanie terminu płatności podatków (Tabela 4). Największy skutek dla budżetu badanej gminy wywołało obniżenie górnych stawek podatkowych, powodując spadek dochodów podatkowych o około 2\%-3\%. 
Do głównych wydatkowych instrumentów wspierania przedsiębiorczości można zaliczyć inwestycje. Na Rysunku 3 zostały przedstawione główne zadania inwestycyjne miasta Katowice w części gminnej.

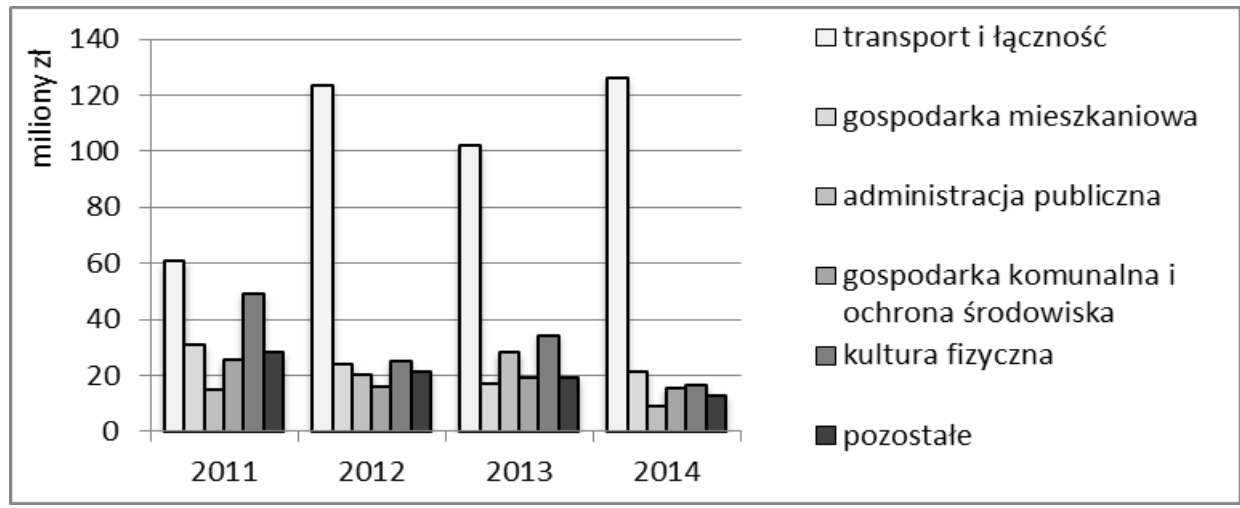

Rysunek 3. Glówne kierunki inwestowania w Katowicach w latach 2011-2014

Źródło: Opracowanie własne na podstawie danych ze sprawozdań z wykonania programu zadań społecznych i gospodarczych Miasta Katowice

Dominującym działem zadań inwestycyjnych w mieście Katowice był transport i łączność. Znacznymi inwestycjami w latach 2011-2014 były także inwestycje w następujących działach: gospodarka mieszkaniowa, administracja publiczna, gospodarka komunalna i ochrona środowiska oraz kultura fizyczna. Inwestycje te przyczyniają się do polepszenia warunków prowadzenia działalności gospodarczej.

Kolejnymi wydatkowymi instrumentami wspierania przedsiębiorczości w mieście Katowice były instrumenty informacyjno-promocyjne. Promocja gminy według prawa należy do zadań własnych gminy. Elementy promocji miasta Katowice zostały pokazane w Tabeli 5 .

Tabela 5. Elementy promocji miasta Katowice

\begin{tabular}{|c|c|}
\hline Elementy promocji miasta & Charakterystyka \\
\hline Logo & $\begin{array}{r}\text { W wersji podstawowej składa się z sygnetu w kształcie serca } \\
\text { i logotypu „Katowice. Dla odmiany” }\end{array}$ \\
\hline Cechy wizerunkowe & $\begin{array}{c}\text { Metropolitalność, dziedzictwo, alternatywa, aktywność, } \\
\text { ekoodpowiedzialność }\end{array}$ \\
\hline Hasło promocyjne & „Katowice. Dla odmiany” \\
\hline Główne kierunki promocji & Miejsce do mieszkania, centrum gospodarcze, centrum spotkań \\
\hline
\end{tabular}

Źródło: Opracowanie własne na podstawie (Przewodnik po Strategii Promocji Katowic 2012)

W komunikacie strategicznym dla marki Katowice kładzie się nacisk na zdolność zaskakiwania, na wielowymiarowość, „inność” jako promocyjny wyróżnik Katowic, a zarazem swoisty magnes, zwracający uwagę odbiorców przekazu na miasto metropolitalne, o silnych śląskich i postindustrialnych korzeniach, a jednocześnie wciąż poszukujące własnej drogi (Przewodnik po Strategii Promocji Katowic 2012). 
W Katowicach wspiera się także firmy oraz różnego rodzaju przedsięwzięcia służące rozwojowi gospodarczemu. W Tabeli 6 zostały przedstawione przykłady wsparcia inwestorów.

Tabela 6. Przykłady wsparcia inwestorów w Katowicach

\begin{tabular}{|c|c|}
\hline $\begin{array}{c}\text { Rodzaj wsparcia } \\
\text { inwestorów }\end{array}$ & Przykłady \\
\hline $\begin{array}{c}\text { Wsparcie marketin- } \\
\text { gowe }\end{array}$ & $\begin{array}{r}\text { Zorganizowanie kampanii marketingowej na przykład w procesie rekru- } \\
\text { tacji pracowników, promocji mieszkań }\end{array}$ \\
\hline $\begin{array}{c}\text { Pomoc w nawiązaniu } \\
\text { współpracy z różnymi } \\
\text { instytucjami }\end{array}$ & $\begin{array}{c}\text { Na przykład szkołami wyższymi, Akademickimi Biurami Karier, izbami } \\
\text { handlowymi }\end{array}$ \\
\hline $\begin{array}{c}\text { Wsparcie finansowe } \\
\text { ze strony powiatowe- } \\
\text { go urzędu pracy }\end{array}$ & $\begin{array}{c}\text { Staże opłacane przez urząd pracy, zwrot części kosztów za zatrudnienie } \\
\text { bezrobotnego w ramach prac interwencyjnych, refundacja kosztów wy- } \\
\text { posażenia i doposażenia stanowiska pracy oraz finansowanie szkolenia } \\
\text { osób bezrobotnych oraz poszukujących pracy }\end{array}$ \\
\hline $\begin{array}{c}\text { Oferta terenów inwe- } \\
\text { stycyjnych }\end{array}$ & $\begin{array}{c}\text { Przekazywanie ważnych informacji o możliwościach inwestycyjnych } \\
\text { i pomoc w procedurach inwestycyjnych }\end{array}$ \\
\hline $\begin{array}{c}\text { Katowicka Specjalna } \\
\text { Strefa Ekonomiczna }\end{array}$ & $\begin{array}{c}\text { Jest właściwą instytucją dla tych firm, które chcą skorzystać z pomocy } \\
\text { publicznej w formie zwolnień podatkowych: ponosząc nakłady inwesty- } \\
\text { cyjne lub tworząc nowe miejsca pracy }\end{array}$ \\
\hline
\end{tabular}

Źródło: Opracowanie własne na podstawie (Dlaczego warto inwestować w Katowicach 2014)

Zachętą inwestycyjną dla przedsiębiorców jest wsparcie marketingowe, wsparcie finansowe, pomoc $w$ procedurach inwestycyjnych oraz pomoc $w$ nawiązywaniu współpracy z różnymi instytucjami. Kolejną możliwością dla inwestorów jest zlokalizowanie ich inwestycji w ramach Katowickiej Specjalnej Strefy Ekonomicznej.

\section{Podsumowanie}

Działania podejmowane w gminie przez jej władze wpływają na kształtowanie rozwoju przedsiębiorczości, rozpatrywanej w kategorii prowadzonej działalności gospodarczej, tworząc zachęty oraz stwarzając warunki dla obecnych i potencjalnych przedsiębiorstw.

Przeprowadzone badania wykazały, że najwyższy wskaźnik przedsiębiorczości wśród miast na prawach powiatu województwa śląskiego uzyskały dwie gminy: Katowice oraz Bielsko-Biała. Natomiast najniższy wskaźnik przedsiębiorczości wystąpił w Jastrzębiu-Zdroju oraz w Rudzie Śląskiej. Liderem pod względem większej liczby powstawania nowych firm niż ich wyrejestrowywania było miasto Katowice.

Władze miasta Katowice stosują wiele instrumentów, które mają za zadanie służyć rozwojowi przedsiębiorczości. Wśród instrumentów dochodowych można wyszczególnić obniżanie górnych stawek podatkowych oraz stosowanie różnych ulg i zwolnień podatkowych. Natomiast wśród instrumentów wydatkowych można wymienić: inwestycje, promocję miasta oraz wsparcie inwestorów. 


\section{Literatura}

1. Drucker P.F. (2015), Innovation and Entrepreneurship. Practice and Principles, Routledge, New York.

2. Dziemianowicz W., Mackiewicz M., Malinowska E., Misiąg W., Tomalak M. (2000), Wspieranie przedsiębiorczości przez samorząd terytorialny, Polska Fundacja Promocji i Rozwoju Małych i Średnich Przedsiębiorstw, Warszawa.

3. Gawroński H. (2010), Zarządzanie strategiczne w samorządach lokalnych, Wolters Kluwer, Warszawa.

4. Jarczewski W. (2012), Pozyskanie inwestorów do gmin, Wolters Kluwer, Warszawa.

5. Jerschina J., Beźnic Sz., Lalik-Budzewska D., Lesińska E., Pytliński Ł. (2010), Standardy obsługi inwestorów w Małopolsce. Poradnik, Urząd Marszałkowski Województwa Małopolskiego. Departament Gospodarki i Społeczeństwa Informacyjnego, Kraków.

6. Kola-Bezka M. (2013), Elementy teorii przedsiębiorczości regionu, [w:] Kosiedowski W. (red.), Przedsiębiorczość i innowacyjność w procesie rozwoju regionów Europy Środkowo-Wschodniej, s. 15-62, Wydawnictwo Naukowe Uniwersytetu Mikołaja Kopernika, Torun.

7. Konstytucja Rzeczypospolitej Polskiej z dnia 2 kwietnia 1997 r. uchwalona przez Zgromadzenie Narodowe w dniu 2 kwietnia 1997 r., przyjęta przez Naród w referendum konstytucyjnym w dniu 25 maja 1997 r., podpisana przez Prezydenta Rzeczypospolitej Polskiej w dniu 16 lipca 1997 r. (Dz.U. 1997 nr 78 poz. 483).

8. Leśniewski M.A. (2013), Ekorozwojowe źródła konkurencyjności gmin w Polsce, CeDeWu, Warszawa.

9. Łukomska-Szarek J. (2007), Działalność inwestycyjna samorządów lokalnych w Polsce, [w:] Wójcik-Mazur A., Łukomska-Szarek J., Wielgórka D. (red.), Wieloaspektowe problemy zarządzania podmiotami publicznymi i prywatnymi w gospodarce polskiej, s. 150-162, Wydawnictwo Politechniki Częstochowskiej, Częstochowa.

10. Piotrowski S. (2012), Konkurencyjność regionalna a innowacyjność i przedsiębiorczość, [w:] Łaźniewska E., Gorynia M. (red.), Konkurencyjność regionalna. Koncepcje - strategie przykłady, s. 134-152, Wydawnictwo Naukowe PWN, Warszawa.

11. Raszkowski A. (2012), Marketing terytorialny a konkurencyjność regionalna, [w:] Łaźniewska E., Gorynia M. (red.), Konkurencyjność regionalna. Koncepcje - strategie - przykłady, s. 152-170, Wydawnictwo Naukowe PWN, Warszawa.

12. Sprawozdanie z wykonania budżetu Miasta Katowice za 2010 rok, Katowice 2011.

13. Sprawozdanie z wykonania budżetu Miasta Katowice za 2011 rok, Katowice 2012.

14. Sprawozdanie z wykonania budżetu Miasta Katowice za 2012 rok, Katowice 2013.

15. Sprawozdanie z wykonania budżetu Miasta Katowice za 2013 rok, Katowice 2014.

16. Sprawozdanie z wykonania budżetu Miasta Katowice za 2014 rok, Katowice 2015.

17. Sprawozdanie z wykonania programu zadań społecznych i gospodarczych Miasta Katowice w 2011 roku, załącznik do Uchwały Nr XXIV/523/12 Rady Miasta Katowice z dnia 27 czerwca 2012 roku.

18. Sprawozdanie z wykonania programu zadań społecznych i gospodarczych Miasta Katowice w 2012 roku, załącznik do Uchwały Nr XXXVIII/861/13 Rady Miasta Katowice z dnia 26 czerwca 2013 roku.

19. Sprawozdanie z wykonania programu zadań społecznych i gospodarczych Miasta Katowice w 2013 roku, załącznik do Uchwały Nr L/1172/14 Rady Miasta Katowice z dnia 28 maja 2014 roku.

20. Sprawozdanie z wykonania programu zadań społecznych i gospodarczych Miasta Katowice w 2014 roku, projekt. 
21. Ustawa z dnia 2 lipca 2004 r. o swobodzie działalności gospodarczej (Dz.U. 2004 nr 173 poz. 1807).

22. Ustawa z dnia 8 marca 1990 r. o samorządzie gminnym (Dz.U. $1990 \mathrm{nr} 16$ poz. 95).

23. Zimny A. (2008), Uwarunkowania efektywności inwestycji gminnych w sferze infrastruktury technicznej, Wydawnictwo Państwowej Wyższej Szkoły Zawodowej w Koninie, Konin.

24. Dlaczego warto inwestować w Katowicach (2014), http://pl.invest.katowice.eu /o_projekcie/22/25/prezentacja_miasta.html (dostęp: 12.02.2016).

25. European Cities Monitor (2011), Cushman \& Wakefield, http://www.cushmanwakefield.co.uk /en-gb/research-and-insight/2012/european-cities-monitor-2011/ (dostęp: 07.06.2016).

26. Główny Urząd Statystyczny, Bank Danych Lokalnych, https://bdl.stat.gov.pl/BDL/start (dostęp: 09.02.2016).

27. Główny Urząd Statystyczny, Statystyczne Vademecum Samorządowca 2015, http://katowice. stat.gov.pl/statystyczne-vademecum-samorzadowca (dostęp: 08.02.2016).

28. Przewodnik po Strategii Promocji Katowic (2012), oprac. Media Partner - W. Czyżewski, M. Lorenc, http://www.katowice.eu/Herb\%20i\%20Logo\%20Katowic/Przewodnik\% 20po\%20SPK_13.11.2012.pdf (dostęp: 10.02.2016).

\title{
MANAGEMENT OF THE MUNICIPALITY IN TERMS OF SUPPORTING ENTREPRENEURSHIP
}

\begin{abstract}
The article presents tasks of the municipality and its role in entrepreneurship development. It shows instruments supporting entrepreneurship, divided into income instruments and expenditure instruments. The aim of the article is to analyze the entrepreneurship considered in the category of business activity in the cities with powiat status of Silesian province and identification actions in support of entrepreneurship in the municipality of the best indicators.
\end{abstract}

Keywords: city with powiat status, entrepreneurship, local government, municipality, tools supporting entrepreneurship 